\title{
Anatomy and the Reconfiguration of Life and Death in Republican China
}

\section{DAVID LUESINK}

This article argues that the establishment of anatomo-power in China preceded and set the foundation for biopower. Anatomo-power is disciplinary power over live bodies in the military, schools, and hospitals, but also the power of the medical profession over dead bodies to investigate pathology through dissection. At the turn of the twentieth century, Chinese conceptions of political anatomy were used to advocate anatomical knowledge, and an anatomy law in 1913 made routinized dissection possible. Chinese society began to be transformed as old taboos were broken, and thousands of new terms allowed the scientific worldview to take root among professionals and the public. Anatomical researchers addressed both microscopic pathology to cure individuals and macroscopic questions that grouped individuals into a population to be managed, or that sought data to tell new narratives about the origins and future of humanity-a new political anatomy based on the practice of human dissection.

Keywords: anatomo-power, anatomy law, dissection, linguistic standardization, physical anthropology, political anatomy, professionalization, racial anatomy, Republican China, taboo

$T^{\mathrm{N}}$ the Early Republic of China, Dr. Tang Erhe introduced an anatomy law allowing 1 routinized dissection for the first time in Chinese history - a change largely unnoticed that had implications not only for medicine and education, but also for the entire worldview of educated Chinese. An anti-Manchu revolutionary at the turn of the century and a prominent participant in the New Culture Movement of the 1910s and 1920s, Tang Erhe (1878-1940) is almost completely unknown outside of China. More important than his intimate association with more famous contemporaries like "father of the nation" Sun Yat-sen or China's most famous modern writer, Lu Xun, was the groundwork Tang Erhe laid establishing anatomy as the basis for modern Chinese science. The new science was no mere academic pursuit for elites like Tang; it was, rather, fundamental to the project of adequately assessing and accessing the vast human and natural resources of China. In contrast to the writer Lu Xun, who had given up the study of anatomically based medicine to become a revolutionary writer with the object of saving China, Tang's prescription for doing the same involved anatomical medicine at its core (Heinrich 2008, 134-47; Lu 1922). Distaste for dissection may have been part of Lu Xun's rejection of medicine, but for Tang, who also studied medicine in Japan and remained friends with Lu Xun until 1920, a key component of national salvation was exactly that—cutting up

David Luesink (luesinkd@sacredheart.edu) is Assistant Professor in the History Department at Sacred Heart University and Associate of the Asian Studies Center at the University of Pittsburgh. 
and looking into human bodies to learn about the structure and pathology both of the individual and of the human species.

Tang Erhe was trained in Japan in the tradition of state medicine developed in Germany and Japan and inspired by physician-politicians like Rudolf Virchow and Nagayo Sensei. This tradition sought to closely link the power of the state to the capacities of the medical profession to regulate bodies for the health of the individual and the nation (Andrews 2014, 69-88; Lynteris 2011; Rogaski 2004). Tang, a physician-politician, was at the center of routinizing medical practice in China between 1912 and 1922: he established two government medical schools and a professional association for physicians, he petitioned for a law to allow dissection against longstanding legal proscription and cultural taboo, he led the standardization of a Chinese nomenclature for anatomy as a representative of the Ministry of Education, he translated German and Japanese textbooks on anatomy for China's leading press, and he conducted and supported anatomical research. For all of these reasons, Tang provides a useful narrative center for this article about the establishment of anatomo-power.

After 1922, Tang moved into elite political circles, serving as cabinet minister three times in the 1920s with briefs for education, finance, and Ministry of the Interior; as advisor to Manchurian warlord Zhang Zuolin and his son, Zhang Xueliang; and as one of three key leaders of the Japanese collaborationist government of North China in the late 1930s. ${ }^{1}$ As minister of education in 1922, Tang continued to increase funding for and otherwise promote government-sponsored medical education as a key part of his government advocacy to increase the power of anatomical medicine in China-that form of medicine that is usually described in Chinese as Western medicine (xiyi) and in English as biomedicine or allopathic medicine.

The introduction of anatomo-politics is a significant and unexamined element in the epistemological and institutional transition from imperial to modern China, and must also be reintroduced into discussions of biopower and biopolitics more generally. To trace this history, the article uses, among other sources, archives from Beijing, existing extracts of Tang Erhe's diary and his many publications, and detailed transcripts of terminology meetings. Examining the activities of Tang Erhe as he sought to establish the conditions necessary for China to adopt these two new technologies of power over life and death allows a fuller understanding of the unfolding of the long Chinese cultural transformation from the imperial Confucian family system of social control to that of authoritarian neoliberal biopolitics today, which might be contrasted with liberal biopolitics in its ongoing reliance on disciplinary and surveillance technologies. The focus is on the two decades between 1912 and 1933 when anatomy went from a euphemistic, disembodied rhetoric of "the whole body" to an institutionalized practice of dissecting human bodies that connected standardized textbooks, medical students, scalpels, and corpses as the basis of medical education with the racial implications of physical anthropology. Traditional views of the body began to be displaced when anatomy and dissection became something a new class of professionals could practice and the educated public could discuss and observe through candid descriptions and images in the media.

${ }^{1}$ On Tang's early pan-Asianism, see Karl (2002, 105-9). On Tang as collaborator, see Boyle (1972) and Taylor (1940). 
This article is an overview of the intellectual, political, and institutional process of one worldview becoming marginalized while a new one was constructed in its place. After briefly reviewing the existing literature on biopolitics in China, it demonstrates how the late imperial context of body knowledge provided compelling reasons to link anatomy with state power, and then explores the career of Tang Erhe and the discipline he established in the 1910s through legal advocacy and educational innovation. Third, it examines the implementation of human anatomy and how it began to transform Chinese language and society, and ends by broaching the significance of racial anatomy as the link between anatomo-power and biopower. ${ }^{2}$

\section{Anatomo-politics and Biopolitics in China}

Tang Erhe argued that for anatomically based medicine to become "apparent" to Chinese elites and commoners alike it was necessary to attach it to the political power of the state. Although he and his Japanese- and German-trained group of physicians believed that anatomical medicine was absolutely true and Chinese medicine false, they were explicit in acknowledging that anatomical medicine could only be established through the backing of state power and a strong medical profession that would regulate Chinese medicine into oblivion, as was attempted by Tang in 1917 and by others in 1929 (Lei 2014; Tang Erhe 1917). The scope of what they sought to establish was not limited to dissection practice for medical students. For its practitioners in China and around the world, the discipline at times subsumed all of the still relatively weak discipline of biology, which was largely investigated from within anatomy departments. It encompassed microscopic disciplines of histology, and cytology, but also those that asked big questions about the origins and destiny of the human race, such as embryology, physical anthropology, paleoanthropology, and evolutionary biology. As a large umbrella under which its practitioners could research questions in all of these fields, anatomy was a vehicle for the dream of remaking China through scientific inquiry in order to penetrate into the mysteries of life itself, either those of the individual or of the population. In his frequent travels to Japan and Germany, Tang witnessed the novel technologies of power over life exercised by modern states there and sought, with some success, to create these conditions in China.

Modern power over life and death has been described by Michel Foucault ([1977] 1995, 135-36) as being constituted by the two poles of anatomy and biology; one exerting disciplinary power over the individual, the other over the population, race, or species. That which Foucault termed anatomo-politics was reductive in transforming the body into a machine, optimized through the discipline of individuals in the school, army, prison, or hospital; this was the useful body. Less emphasized in Foucault's later work, anatomo-politics was also reductive to the level of gross and microscopic anatomies that peered into tissues and cells for the destiny of that individual; this was the intelligible body (135-69). Biopolitics, which in France developed somewhat later than anatomo-

\footnotetext{
${ }^{2}$ This is a constructivist approach to science in the first half of the twentieth century that emphasizes the perceived utility of the new knowledge; a historical survey of anatomical knowledge in China, even for the nineteenth century, is beyond its scope.
} 
politics, expanded the nexus of power beyond the individual to the level of the population through the use of the statistical controls associated with public health and demography, yet it rested on the disciplinary foundation of its predecessor. For Foucault (2003, 239 63 ), biopolitics is primarily a system of power appropriate to liberal capitalism that seeks to improve the health and efficiency of citizens by eliminating the "waste" of human energy from work absenteeism, infant mortality, or premature death.

The key to the liberal approach to biopolitics is that individuals willingly join in the project of regulating themselves to improve their work efficiency and health, a project described in the context of post-socialist China by Judith Farquhar and Qicheng Zhang $(2005,303)$ as a space of contestation that both "supplements and resists modern power." Yet in the early twentieth century, few intellectuals in China were calling for democratic participation and individual rights for all; first the vast untapped energies of the people had to be unleashed through disciplinary measures enforced by a modern police force and the ideological apparatuses of the party-state. The state would discipline and punish, but also provide means to investigate detailed knowledge of the body evident only through routinized human dissection.

The recorded actions and words of reformers like Tang Erhe demonstrate that he implicitly recognized that anatomy twinned with state-enforced standards of hygiene could link the possibilities of the individual body with those of the population, yet existing scholarship has focused only on the development of biopower in China. Ruth Rogaski $(2004,300)$ has described Meiji-era Japanese physicians who, "from their perspective on the outside of the European Enlightenment project, quickly grasped some of the core elements that made the West appear 'modern' and sought to employ them as 'full kits' to transform their own societies." In the late nineteenth century, Nagayo Sensai argued that eisei, usually translated as hygiene, was not limited to individual or even collective health, "but instead points to the particular type of governmental structures that are in charge of protecting the general health of the state's citizens"-a level of state intervention not previously undertaken in East Asia (quoted in Lei 2009, 48-49). ${ }^{3}$ Because eisei/weisheng encompassed more than the European concept of hygiene, Rogaski argues that it might best be translated with the term "hygienic modernity." Rogaski also claims that the modern version of the Japanese concept eisei, or weisheng in Chinese, should be understood as encompassing Foucault's notion of biopower. Other scholars have productively used the concept of biopower to analyze the development of Chinese government interventions in the population, such as Susan Greenhalgh (2008) on the one-child policy in post-socialist China. Sociologist Ying Xing (2009, 134) sees the birth of "Western biopolitics" in China (xifang shenti zhengzhi) in the first modern census of the population in 1908, while Malcolm Thompson (2012) reveals that governmental interventions in the population in early Republican Chinese discourse established a basis for the One Child Policy in the 1980s. Tong Lam (2011) has explored the production of social surveys in the Republican period in order to aggregate individuals into populations that could be statistically understood, so that government and elites could intervene in "social problems." The biopolitical has also been

${ }^{3}$ Tang Erhe was a close colleague of Nagayo's son, Mataro, a leading anatomist; he visited him often in Tokyo and translated his book on medicine and philosophy (Nagayo 2001, 1:600; 2:250, 264, 270, 274, 282). 
explored in discourse about suzhi, or the quality of the population, where "[l]ife itself becomes something that requires regulation and protection, a concept neatly packaged in the Chinese term for 'hygiene'-weisheng”' (Sigley 2009, 541). Mei Zhan (2011), however, warns that the idea of biopower for Foucault was always historically specific, so that each context deserves careful analysis. Accordingly, Sean Lei $(2014,261)$ channels Pierre Bourdieu as much as Foucault to argue that Republican physicians themselves created the medical capacity of the state as they colonized, composed, and transformed government to suit their vision of state medicine.

All of these accounts do not quite grasp the ways in which governing bodies had to take hold of individual bodies before controlling the collective. Yet their insights compel us to move beyond Foucault's accounts of France to examine the historically specific development of anatomo-power in China as developing before, and along with, biopower. But before observing anatomo-power in action, a brief survey of body knowledge in China before the anatomy law must be conducted to understand what was being reconfigured.

\section{The Late Qing Context for Anatomy}

By the end of the nineteenth century, a Confucian correspondence of heaven-body-earth led writers to interpret crises of the state as pathologies caused by improper rule, yet they innovated on that theory by arguing that "incorrect" views of the human body were part of the problem. The publication of Yan Fu's widely read translations of Thomas Huxley (1896-98) and Herbert Spencer (1903) brought the concept of social Darwinism to Chinese elites, which they interpreted as the survival of the fittest nations in the unrelenting global capitalist competition for wealth and power. In Yan Fu's hands, China became a social organism analogous to a biological one: "When a social group is formed, in terms of its structure and functions, in terms of its capacities, it does not differ from a biological entity. While differing in magnitude, there is a similar correspondence of organs and functions" (Schwartz 1964, 56).

For Confucian thinkers, each human body was not an autonomous entity, but part of the cosmos. Both the macrocosm of the cosmos and the microcosm of the human body were understood as systems organized like the imperial bureaucracy: the link was the emperor whose attention to rites and good governance kept each thing in its right place (Zito 1997). Corresponding to this, Chinese medicine also saw the body as a mirror of the state, and the state was seen as mirroring bodily hierarchies. The heart was the emperor, and the other organs took their place as righteous officials managing the realm (Sivin 1995, 7). This line of thinking is ubiquitous in Chinese texts from antiquity to the nineteenth century.

In 1898, the scholar-reformer Tan Sitong (1865-98) charged that China's geopolitical weakness could be linked to incorrect knowledge of anatomy due to the Confucian taboo against cutting dead bodies and legal restrictions. What was at stake was no less than "saving the nation from extinction and saving our lives." His argument closely follows the Confucian cosmology: "if one lives between heaven and earth and knows neither heaven nor earth, this is already a disgrace; if one also is ignorant of one's own body, is this not even more ridiculous?" Tan argued that Chinese medical books could not 
match the accuracy of books from Western countries whose authors based their writings on first-hand dissections. He made detailed anatomical descriptions of the heart, lungs, and other organs, calling this the "elaborate machine of the whole body." His essay ended with a lament for China's internal disorder and a solution: the creation of a new form of militia "defense forces" disciplined by military drill. Confucian academies were to become modern schools to cultivate talent and combine the power of officials and masses to eliminate the problems of the country. Then "each and everyone's whole body could be put at ease" (renren zhi quanti qi keyi an yi); the use of quanti would indicate that he was influenced by missionaries' euphemisms for anatomy like Quanti xue. Quanti here strongly implies the body of the individual, while at the same time bringing to mind its more metaphorical meaning as the whole group (Tan [1898] 1981, 403; 1911, 24). By linking anatomical knowledge based on dissection to the discipline and strength of the country, Tan Sitong can be said to have identified that which Foucault later called anatomo-power. The microcosm of proper anatomical knowledge would lead to successful rule of the realm, the macrocosm, because political legitimacy was connected to accurate knowledge of internal organs.

At the turn of the twentieth century, others of Tan Sitong's colleagues paired the understanding and discipline of the body to the control possible through biopolitical knowledge of the population. The late Qing radical thinker Mai Menghua (1875-1915) described both forms of power, arguing that the heads of state in European nations had more power than the Chinese emperor because they recorded the vital statistics of each citizen, while in China the state could not intervene in such personal matters. Children in the West were sent to elementary schools where they were taught to become loyal citizens and diligent workers, while in China 70 to 80 percent of the people were illiterate and undisciplined. In Western countries, the government controlled the currency, built wide roads, privileged railroads over homes and gravestones, and certified practitioners of medicine. China did none of those things, according to Mai; instead roads were full of beggars and corpses and the state did not have the capacity to deal with them. Medical practitioners, meanwhile, were failed scholars looking for an easy profession, and casually killed patients with no fear of punishment (Mai 1898; Zarrow 2012, 62-63). Not all of Mai's comments were true-the Qing Code regulated incompetent doctors who killed or injured (Neighbors 2004, 38-40)—but he was correct to identify that the power of Euro-American states was greater than that of the Qing because they incorporated the anatomo-power of policing and compulsory education and the biopower of the census and the bureau of hygiene.

Knowledge of the actual structure of the body had been important to physicians and scholars, yet there were extreme limits on the use of dead bodies to acquire such knowledge. In the late Qing, desecrating a corpse by cutting it or even mistakenly opening a grave were serious breaches of the law and of neo-Confucian orthodoxy. NeoConfucianism held that the body must remain intact after death; in the Classic of Filial Piety, Confucius argued against any kind of self-harm or bodily mutilation. The Qing legal code was also explicit that disturbing the remains of the dead was illegal and unfilial and would lead to severe punishments, including lingchi, the "death by a thousand cuts." The state retained the prerogative to transgress the taboo and administer what was in effect a live dissection until death as the ultimate punishment. Although clearly very painful, lingchi was seen by Qing subjects as abhorrent because the convicted 
was unfilial for entering the next life in pieces (Brook, Bourgon, and Blue 2008, 55-61; Jones 1994, 35, 260-63, 274). The Qing Code refers to what Foucault has called sovereign power, the right to take life or let live, but the coming of China's anatomy law in the twentieth century led to a shift to the biopolitical era that instead sought the right to make live and let die.

\section{Tang Erhe and the Anatomy Law}

Reformist intellectuals like Tan Sitong and Mai Menghua had only their written words to inspire change, while a new generation sought to apply practical knowledge and institutionalize new forms of power. Tang Erhe, born an ethnic Chinese Muslim in Hangzhou, became a political and cultural revolutionary by studying Yan Fu's translations of Rousseau and Huxley along with anti-Manchu texts (Boorman 1970, 228; Xu 1991, 1188). Tang's generation increasingly looked to Japan for models of how to achieve national strength, especially after the Qing's humiliating defeat by Japan in 1895, after which thousands of students went to Japan for scientific, technical, and military training (Andrews 2014; Reynolds 1993; Rogaski 2004). In 1902, Tang entered a Japanese military institute in Tokyo, and then, in 1905, changed direction and returned to Japan to study medicine at Kanazawa Medical Technical College (Kanazawa igaku senmon gakkō).

In these years, Tang witnessed Japan's victory against Russia in 1905 and its state medical prowess at home and in its colonies. Throughout the nineteenth and early twentieth centuries, science in Japan was led by developments in medicine, with anatomical investigations leading in that field (Bartholomew 1989, 4; Hasebe 1912). Anatomical medicine had become dominant after 1876, when the Meiji government required all physicians of Chinese-style medicine ( $k a n p \bar{o})$ to study Western medicine; in 1883 the government instituted regulations making kanpō all but illegal. Eisei in Japan became a police matter in the German style, a practice that spread to the Japanese colony of Taiwan after 1895 under its first governor, the physician Gotō Shinpei (M. Liu 2009, 48-53; Lynteris 2011).

Tang experienced a personal and professional awakening while studying medicine in Japan, coming to the same conclusions as Tan Sitong: Chinese notions of anatomy must be transformed with political and police measures so that China's strength could be returned. Yet, Tang Erhe saw political revolution as necessary, whereas Tan Sitong had remained a monarchist and reformer. Like some of the "progressive medical elements," Tang was ashamed that foreign elements were planning to transform the medical field on behalf of China, so without the help of the Qing government, he "gathered together colleagues and established medical schools and planned their development” (Bao 1931, 4). The first medical school he established was in Hangzhou in 1911, where he soon found the business of establishing medicine overshadowed by larger events. He participated in the 1911 revolution, organizing militia units and negotiating the surrender of the local Manchu garrison. He then served as a Zhejiang representative in the provisional government in Nanjing, where Dr. Sun Yat-sen was elected president of the new republic and Tang himself presented Sun with the certificate of office. Yet six weeks later, the two physicians were no longer at the center of national politics-Sun withdrew in favor of strongman Yuan Shikai, and Tang returned to Hangzhou. When Tang was invited to become a 
representative at the National Education Assembly in Beijing, he made a case to the Minister of Education that medical schools should be a greater priority than schools of law and politics. To create a modern government with new forms of power, he argued, following Mai Menghua, each branch needed physicians, including the army, the courts, schools, cities, epidemic bureaus, police, and customs (Tang Yousong 1942, 40-46).

So when the Minister of Education asked Tang to set up a model medical school in the capital, Tang insisted that it be a school of Western medicine only, not a hybrid with Chinese medicine, whose anatomical ideas he considered absurd (Tang Erhe and Chen Duxiu 1918; Tang Yousong 1942, 49-51). Cultural revolutionaries like Tang and his colleague Chen Duxiu followed Yan Fu in seeing an analogy between the health of an individual and the health of society: "If the old and rotten cells accumulate and fill the body, the person will die. If metabolism functions properly in society, it will flourish; if old and rotten elements fill the society, then it will cease to exist" (translated in Chow 1960, 46).

The key to ensuring the health of the young members of society was discipline and hygiene, and Tang followed the Japanese pattern in his National Medical College in Beijing, where "[m]ilitary discipline prevail[ed] throughout the medical course" (Cowdry 1920b, 76). E. V. Cowdry, chair of the department of anatomy at the Rockefeller Foundation's Peking Union Medical College (PUMC), saw such discipline as essential so that China's doctors might "lead the mass of the people to see themselves as others see them and to assume full responsibility for the orderly development of their own lives" (Cowdry 1920a, 39). Military discipline at Tang Erhe's medical school is evident in a photograph of the incoming 1913 class of students dressed in uniforms and holding rifles (see figure 1). Mai Menghua and Tan Sitong had thought their fellow countrymen undisciplined, messy, and inefficient, while physicians lacked discipline and morality; Tang Erhe now offered a plan to transform Chinese bodies, beginning with his students, that exemplified anatomo-power.

The militarization of the larger Chinese citizenship spread by the late 1920s to the growing number of public schools, many located in the rich lower Yangzi River region. Robert Culp describes how students' time was increasingly "industrialized," as they were trained in daily routines of sitting for hours in classes and practicing mandatory physical training and sports, learning how to compose their bodies in a variety of new disciplined spaces such as playing fields, gyms, and laboratories. By the time the Nationalists established their regime in Nanjing in 1928, there was an increasing militarization of students, which for Generalissimo Chiang Kai-shek was an anatomo-political attempt to "temper bodies and minds" with military drill, but for the students who themselves clamored for it, such training was seen as essential to resist the Japanese (Culp 2007, 163205). One author from this period called for a complete "body revolution" (shenti geming) where bodies disciplined by tiyu (body cultivation) would become increasingly strong and healthy (Mou 1929). This was a transformation of the body into a machine: efficient, useful, and docile. A 1933 public health poster that compared the human body to a factory made up of a network of machines demonstrates how a mechanistic view of the body might be disseminated (see figure 2). The lungs are bellows, a hand is a bucket digger, and the brain is a corporate manager. In the bottom left panel, the body of a young man is broken down into its biochemical components, further emphasizing its machinelike qualities. Tan Sitong had tied together the need to understand the 


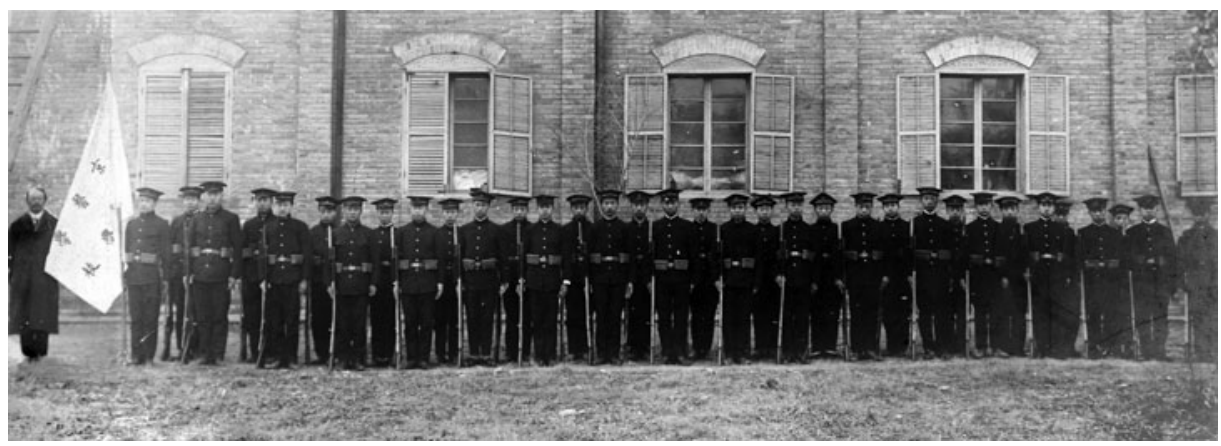

Figure 1. January 1913, first class of seventy-two students recruited from Beijing and Shanghai. Image is of first cohort during military drill (PUHSCAC 1913). Courtesy of Archives of Peking University Health Science Center.

human body reductively as a machine with the anatomo-politics of military drill. By the 1930s, the mechanistic-reductionist view of the body was becoming successful in China because its knowledge system paralleled the success of industrial capitalism. The body-as-machine worldview corresponds "to the daily experience of capitalist life, making its precepts seem self-evident" (Lewontin and Levins 2007, 125). There was resistance to school and state goals, as when students insisted on protesting against warlord policies of the 1920s and 1930s against the admonition of administrators like Tang Erhe, but the anatomo-political disciplines increasingly became part of the lives of students, who then reproduced them for the next generation.

Tiyu was a key point of contact not only between anatomy and the new education system, but also for the somatic disciplines of anatomo-politics and encompassed both the Anglo-American tradition of physical education and team sports as well as the German-Japanese tradition of physical culture. To discipline one's own body, first it must be understood. Beginning in the late Qing, but accelerating in the twentieth century, there were calls from the likes of Yan Fu, Tan Sitong, Sun Yat-sen, and Mao Zedong for tiyu to transform weak Chinese bodies through disciplined and militaristic physical training rooted in the science of physiology and anatomy. By the 1930s both the Nationalist and Communist parties had variations of a tiyu for the masses (minzhong tiyu) that sought to strengthen the social body and led to increased health and reduced poverty (Morris 2004, 106). Tiyu specialists like Wan Weicun argued that knowledge of basic physiology and anatomy for physical education was essential for all educators, athletes, and their trainers. Tiyu required knowledge not only of the internal organs, but also the complex structure of muscles and tendons that ancient Chinese anatomy had largely ignored, as well as the body's systems like the autonomic nervous system that controls functions such as heart rate, digestion, respiratory rate, pupillary response, urination, etc. (Wan 1934). Students would be taught basic anatomy in tiyu class, and would experience the value of exercise for the health of their body through movement itself.

For medical students, anatomo-politics also needed to be connected to the anatomoclinical method, also known as pathology. Certainly students must be disciplined with military training, and new concepts of hygiene inculcated so that they might, in turn, give lectures on hygiene among the people, but also necessary was establishing medical 


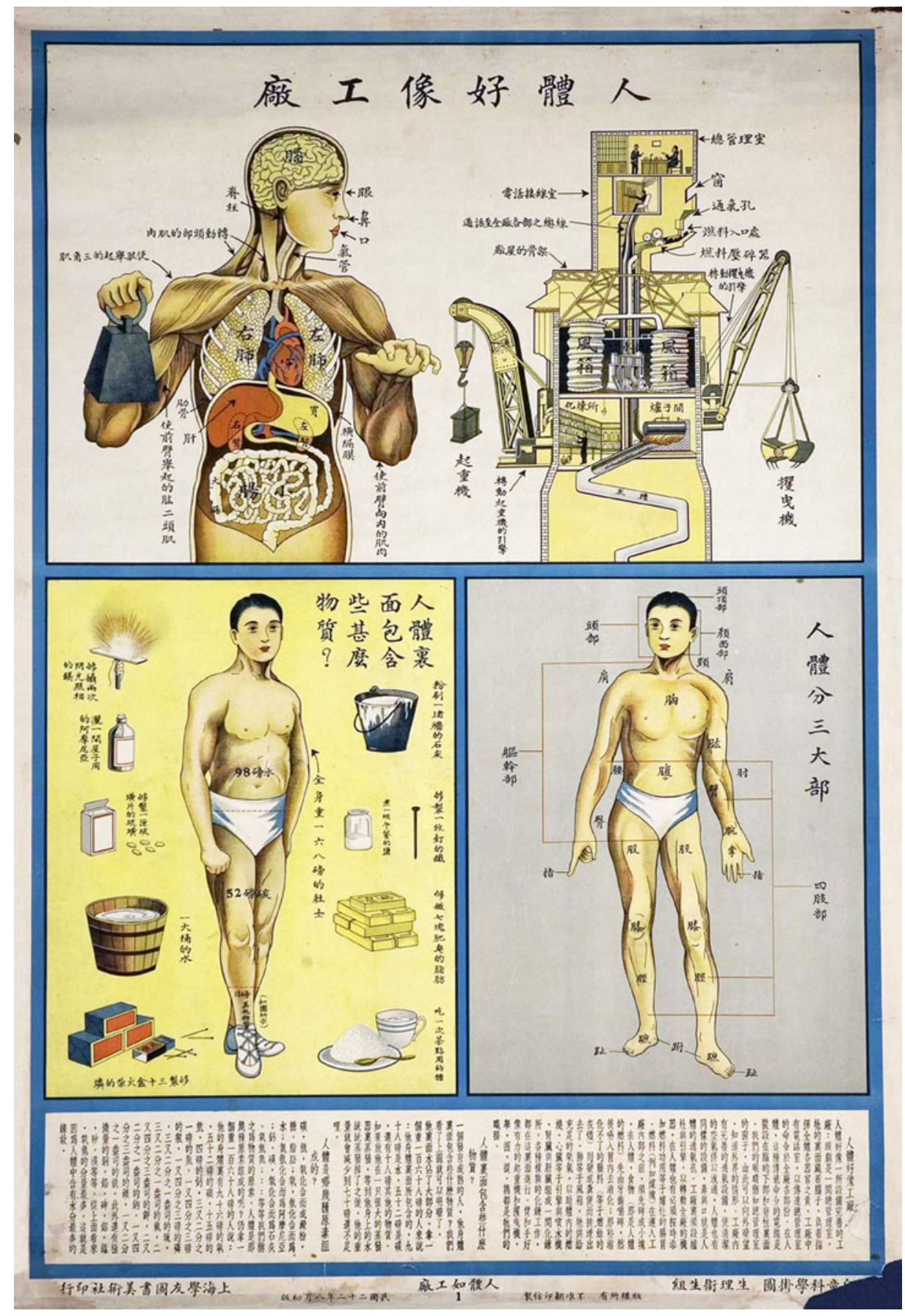

Figure 2. "Renti hoaxing gongchang" [The human body is like a factory], 1933. Shanghai: Shanghai Xueyou Tushu Meishu She Yinxing. Courtesy of US National Library of Medicine. 
power over the bodies of patients who lived with symptoms and died with anatomically identifiable lesions. As Laennec, inventor of the stethoscope, explained it, “[p]athological anatomy is a science whose aim is the knowledge of the visible alterations produced on the organs of the human body by the state of disease" (Duffin 1998, 286-88). Pathological anatomy was born in the wake of the French Revolution, when physicians took control of the bodies of the poor in hospitals from the church, and were able to record symptoms of the sick and dying and link them with abnormalities visible in postmortem dissection. For fifty years, Paris became the global center of medical education as the state made the bodies of criminals and the poor available for dissection, and foreign students returning to Great Britain, Germany, and the United States carried the anatomo-clinical method throughout the world (Weiner and Sauter 2003).

Following this trend, in late November 1912, Tang began petitioning the government for anatomical material-cadavers_ - "so that China could catch up with Western countries." He argued that human anatomy had been the basis for medicine "in all nations" for more than seven centuries, while China was one of only a few that had ignored it. Neither claim was exactly true, but it nonetheless made for a compelling argument. Because dissection had been taboo in China for thousands of years, he reasoned, perceptions of the body had become absurd and medical practice had declined. The government needed to initiate the requisite reforms: establish a sufficient number of medical schools, create teacher-scholars, provide dissection material, and make regulations to replace the old style physicians with new medical practitioners. The key was finding a regular supply of bodies. Tang's solution was to follow the example of Western nations, where "the context for anatomy ... had already evolved to the point that various methods of collecting corpses have accumulated among which to choose" (BMA 1912$15)$.

Tang argued that German laws were the most relevant: "As to the method of acquiring corpses, there are discrepancies in each country, but among those best equipped there is none like Germany." Chinese legal reform at the time was deeply influenced by the German Civil Law code of 1900 (Bourgon 2004; Mühlhahn 2009). Germany’s anatomy laws facilitated the collection of "dissection material" from a variety of sources, including the corpses of executed prisoners, prisoners who had died while incarcerated, the bodies of those who had committed suicide, fatalities in a hospital or pauper's facility, and the truly poor who had no money to manage a burial. While he identified the bodies of executed criminals as constituting "without doubt the majority," he later contradicted himself in arguing that fatalities in a hospital or pauper's facility "make up the largest portion of dissection material in Western countries." In such cases, "dissections must not be forced, with the exception of those cases where the family of the deceased or other related people are unwilling to pay the hospital fees for medicine, food and drink, or burial": these could be turned over for dissection.

Tang's proposals were returned many times with amendments, beginning what his son called "a war of words" (Tang Yousong 1942, 67) before the four substantive provisions to China's first anatomy law were promulgated on November 22, 1913. Each gave significant power to family and friends to retain the body after dissection, but nonetheless, the nascent medical profession gained the authority to conduct autopsies to determine cause of death and conduct experiments and demonstrations using the bodies of those who died without family or friends or who donated their bodies (Bao 
1931, 13-14). In March 1914, the Shenbao published an article called "Opponents of the government dissection law" (Bu ding jiepou guize zhi fanduizhe) in which the only opponent named was Tang Erhe himself, confirming a gap between the scope of his original proposals and the law that was implemented (Shenbao 1914). One of the new provisions he advocated explicitly allowed all medical schools and hospitals throughout China, whether public or private, to begin teaching, researching, and conducting autopsies on the bodies of the dead, bringing China one step closer to Tang's ideal of a large number of properly trained physicians employed throughout government and society. A second would allow the creation of anatomy museums where normal or abnormal specimens could be preserved in chemicals in glass jars and observed and compared at leisure, rather than sewing up all parts inside to be buried with the body (see also Bao 1931, 15-21). These provisions were added to the anatomy law on April 22, 1914, allowing a growing number of medical schools throughout China to practice human dissection.

Key to accessing these bodies were a series of new institutions that gave the state and the medical profession power over individual bodies, whether it was hospitals, prisons, or workhouses where the dead bodies of unclaimed paupers were fair game for dissection practice. Each of these institutions sought to produce docile live bodies, but also useful dead ones; this was the connection between anatomo-politics and anatomy.

\section{Human Dissection in China}

The first human dissections in various provinces and medical schools were witnessed by officials, recorded by the press, and sometimes described by participants themselves. Examining some of these accounts demonstrates how Chinese individuals and society first began to encounter human dissection as a practice that could transform not only cosmology, but also the realities of life and death. Some dissections occurred before the initial law was passed, as in Harbin and Mukden (Shenyang), where numerous dissections were conducted under the exceptional circumstances of the 1910-11 pneumonic plague epidemic. A few autopsies were conducted in 1912 in Guangzhou with permission of the local government, and in an event widely publicized as the first legal dissection in China in Suzhou, with the permission of the governor, just before the anatomy law was promulgated in November 1913 (Jiangsu Provincial Medical College 1913; Wong and Wu 1936, 598). After the anatomy law, the first dissections occurred in Hubei in 1914, in Zhejiang in 1915, and later in more conservative provinces like Shandong in the east and Sichuan in the west. Yet E. V. Cowdry (1920a, 45) claimed that by 1920, only twelve of twenty-six medical schools in China had regular courses in human dissection. Still, this number continued to increase as the relationship between the state and the new medical profession continued to deepen with the Nanjing-based government of Generalissimo Chiang Kai-shek after 1928.

Chinese anatomy students published accounts of their encounters with dissection, revealing their contemplation of the lives of those whose bodies lay on the dissecting table. "Filled with a fearful and curious state of mind, I step into the dissection room," Zeng Jian began his "Pilgrimage to the dissection room." Zeng castigates himself for his cowardice and fear seeing his first dead body, after a lifetime of avoiding funerals. 
Below a white cloth was a skeleton without a head, "the upper ribs one by one vaulting like an arch, making a half circle, but not scraped completely clean, leaving little threads hanging on top." A cross-section of the cadaver's thigh revealed fibrous wrinkles, "just as if one left out red-cooked beef a day too long." These accounts routinely ponder the life of person whose dead body the student must now cut and pry apart: "Was he not just as alive as us not long ago, a person able to move, with thoughts, with feelings, with love and with hatred?" The other medical students, Zeng sees, lower their heads, grab an arm or leg, and look earnestly at their textbooks, while Zeng wonders if they are also preoccupied with thoughts of life and death (Zeng 1933). In a 1914 photograph, students at the National Medical College practicing dissection are clad in white uniforms, their heads bent over their cadaver, one working in the area of the head, one dissecting a hand, one the knee, and a fourth the foot, with this arrangement repeated at three or four other tables while three teachers carefully supervise (see figure 3 ).

Another student dissector was also preoccupied with existential questions of life, death, and the injustice of a world where anyone could end up on the dissection table given the wrong circumstances. A poem published under the name Ke Feng (1937) reveals the student worrying about the "limitless sorrow" of the poor on the streets who will "die of cold with no one to encoffin" them, thus finding themselves in the dissection room "full of the smell of chemicals and death":

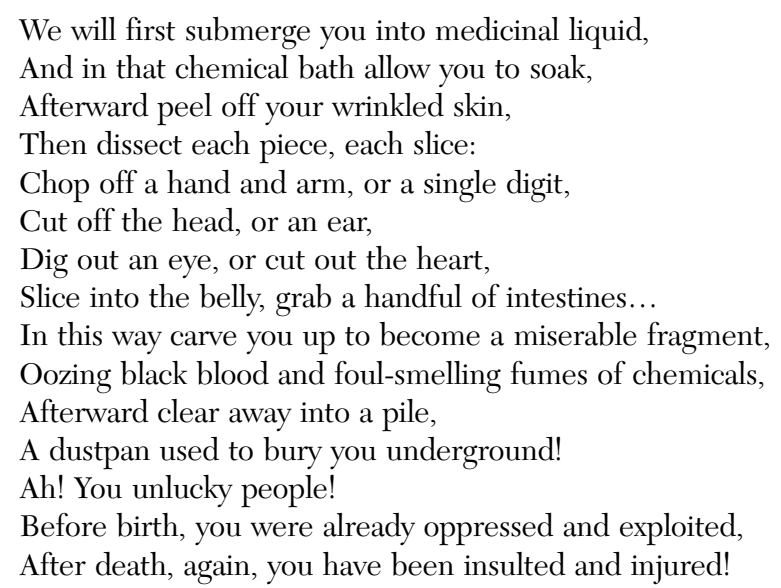

These were the thoughts of novices, similar in tone to the text and pictures produced by medical students at the University of Massachusetts Medical School between 1989 and 2002 (Bertman 2009). These recent American students described the lifelong impact dissection had on them, but a century ago, any feelings American medical students might have for the dead were suppressed in a spirit of "professionalism," and the very act of dissection rendered their "hearts liable to be corrupted and hardened ... [and] brutalized the feelings" (quoted in Warner and Rizzolo 2006, 404). In China, the bodies of the dead were likewise objectified as "dissection material" (jiepou cailiao) in medical sources, official documents, and newspaper articles for the public (e.g., Shenbao 1935). Even Zeng Jian, after looking carefully at his cadaver, decided it was better to consider the body just a pile of ethyl alcohol-smelling bones and muscles than to "think about what this thing actually is" (Zeng 1933). 


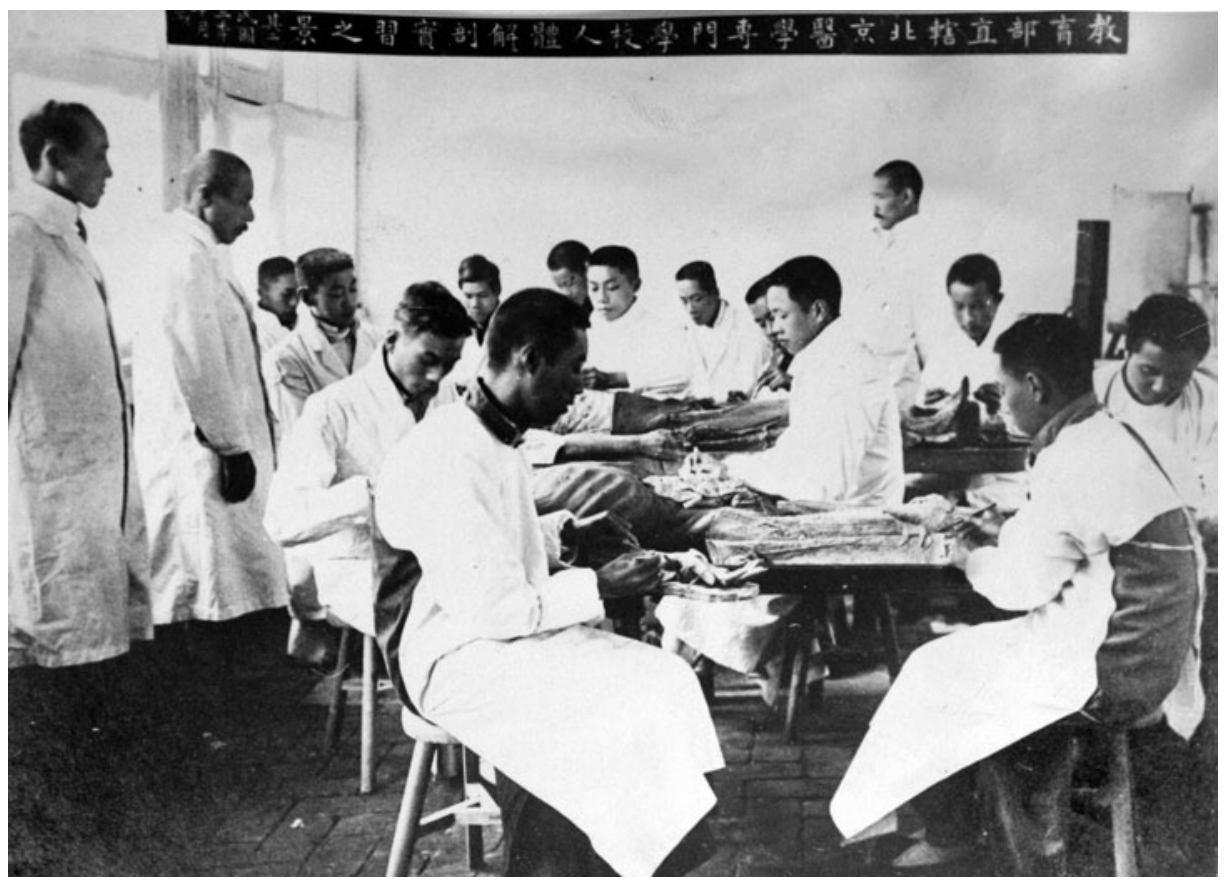

Figure 3. 1914 anatomy practice at Beijing Medical Professional College (National Medical College) (PUHSCAC 1914). Courtesy of Archives of Peking University Health Science Center.

Archival records from the Beijing police move beyond the speculation of students to reveal who might end up on a dissection table. Between July 31, 1932, and September 30, 1933, for example, the district commander Yao Junshen of the outer fifth district police station filed a report that lists the date a body was transferred, name, cause of death, last known address, sex, and destination hospital for thirty-four bodies delivered to Beijing's two medical colleges. Liu Chengqing was executed by shooting and delivered to PUMC on July 31, 1932, and his last known address was near the Temple of Agriculture; Lü Hanchen was delivered to the National Medical College on August 13, 1933, having died of illness in a refugee convalescent facility; a nameless male hung himself and was delivered to the National Medical College on August 17 of the same year, having been found in Puchenshi Alley; and another nameless male dropped dead and was delivered to the National Medical College on August 23, having been found in the third alley of East Tianqiao Market. Only two reported cadaver transfers occurred in 1932, both on July 31, with ten in August 1933, and twenty-two in September of the same year, apparently indicating a seasonal nature to the transfers and perhaps also to death itself. The names of twenty-three were known, while eleven could not be identified in death. Only one on this list died by suicide, two dropped dead (both nameless), eight were executed criminals, and twenty-three died of unspecified illnesses (BMA 1931).

Tang sought to include a provision in the anatomy law that would require medical schools to conduct a memorial service once each year to inter the bodies of those who had been dissected. This provision was not included in the 1913 law or the 1914 supplements, but there is mention of a funeral for unclaimed bodies and a sign marking the spot 
of burial. The National Medical College established the memorial service as a sacred ritual beginning in 1915, making April 30 an institutional holiday, and requiring all students and staff to attend the ritual at a plot of land purchased for this purpose in Caihuying village just outside Guang'an Gate (BMA 1912-15, 15). These ceremonies were also advertised to the public in newspaper advertisements, along with names (if known), so that friends and family might attend. At some point after 1944 these services ceased to be held by the National Medical College, only to be rediscovered in the first decade of the twenty-first century to demonstrate respect for the "silent mentors" and encourage cadaver donations (Guo et al. 2012). ${ }^{4}$

The early memorial services were as much about creating goodwill among wary officials and the public to secure an ongoing supply of cadavers as they were about respect for the dead. In 1929, officials of the National Medical School requested bodies of executed criminals from the authority of the Hebei High Court, asking for a telephone call so they could send someone to come and pick up the corpse and insisting that although they might remove specimens, they would not "take one hair that is not needed." After the dissection was complete, they assured the authorities, "each year we hold a ceremony led by the Chancellor of the medical school and attended by all students to respect the spirits" (BMA 1928). Such measures were necessary because of numerous remaining obstacles to dissection. There were rumors in Beijing that the National Medical College practiced the "inhuman lingchi," and that it was haunted by the ghosts of the dissected (Tang Yousong 1942, 68). So although dissection had become legal in practice, "a single piece of paper" - the anatomy law_could not overcome thousands of years of prohibition (68).

In China the difficulty of acquiring "human material for dissection" was deemed to be "the greatest stumbling block in the teaching of anatomy" (Cowdry 1920a, 45). At the National Medical College, archival and college reports do not agree, but there were between thirty-six and thirty-eight corpses received between 1914 and 1917, an average of about nine per year with a high of sixteen in 1915 and a low of either three or seven corpses in 1916 (BMA 1922). In practice, medical schools needed to submit requests for bodies according to the provisions of the anatomy law. In 1920, Cowdry said the PUMC had only been able to receive four bodies in eighteen months, and in 1925 PUMC officials asked the police commissioner that the unclaimed bodies of paupers dying in the streets be turned over to the college (Cowdry 1920a, 45; RFA 1925). Similar requests found in the Beijing Municipal Archives indicate that they were routine, and were occasionally reported in newspapers, as in 1923 when the Tongji Medical School requested that a Jiangsu prison provide bodies for dissection (Shenbao 1923). Although low for the twentieth century, these numbers are nonetheless similar to those of Great Britain in the early nineteenth century, when dissection experience was becoming the foundation of medical education and even illegal exhumation of the dead might only procure two or three bodies in all of Scotland in the course of a year (Bonner 1995, 86).

Despite such obstacles, anatomy practice began taking place on a regular basis in early Republican China for the first time. Although human dissection formerly was an

${ }^{4}$ For the last record for this ritual, see BMA (1939). 
exceptional, hidden, and forbidden practice, the anatomy law allowed the practice to enter the public sphere and become the basis for the new medical profession, transforming state-sponsored cutting of the body from a horrific capital punishment to a discipline necessary to transform the living habitus of medical students, and through them, the larger public.

\section{Making Anatomy Expressible}

The practice of human dissection would allow a medical student to experience a kind of medical enlightenment, but the bones, muscles, tissues, and cells of the body needed to be made legible. This required textbooks and research journals in Chinese and a unified terminology for anatomy. The translation projects of the late Qing were critiqued as "disorganized, unselected, incomplete, ignorant of conflicting interpretations," and "concerned solely with quantity" (Reynolds 1993, 124). For elites in the early twentieth century, the new knowledge could not merely be appended onto that of the ancients, and a revolution in knowledge required vast new terminologies that shifted basic conceptions of the world. "As words change, the world changes," writes Carol Gluck (2009, 3), describing succinctly a growing body of literature that examines both the translation and proliferation of new terminologies in the fields of science and technology. Meng Yue $(2006,31)$ calls this "semiotic modernity," and Lydia Liu (1996) "translingual practice," where in China translators took advantage of the affinity between the written languages of China and Japan to introduce modern concepts through imported vocabularies and texts.

The anatomo-clinical method required thousands of terms to describe previously unseen interior surfaces of the body, so that all that became visible under the anatomist's scalpel could become expressible in language. This process also worked in reverse, especially for medical students, who could only "see" the significance of the interior surfaces because they had become "wholly expressible." Action would produce knowledge only if there were terms to fix it: "by saying what one sees, one integrates it spontaneously into knowledge" (Foucault [1973] 1994, 114-15). Dissection of a human body would allow a medical student like Zeng Jian or Ke Fang to experience medical enlightenment only if combined with scientific classification and a unified terminology. Chinese medicine was considered inadequate for its inability to see, name, and dissect the multitudinous tissues of the body. For the new anatomic epistemology demonstrated in the dissection room, there would be no debate about the existence of the Triple Burner as in the late Qing; by 1916 the debates were between someone like Tang Erhe arguing for the adaptation of the Japanese term jiepouxue for anatomy, literally "the study of dissection," and missionaries like Philip Cousland defending terms like tixue, "the study of the body."

Tang Erhe had started translating Japanese textbooks during medical school to make ends meet, and by the 1910s, he had become medical editor for China's largest modern publisher, the Commercial Press (RFA 1916). Over the next few decades, he published a long list of books on anatomy that included titles on its subdisciplines, such as Histology (1914; 1930 2nd ed.), Topographical Anatomy (1915), Embryology (Ontogeny) (1919), Outline of Anatomy (1925), and Essential Writings on Anatomy (1938), but also books that explored the outer boundaries of anatomy as a science aiming to understand and 
control life, such as two on biology (in 1926 and 1929), and one on physical anthropology (in 1930).

When two professional associations for Chinese physicians of the new medicine were established in 1915, one of the first things they did was call for the standardization of terminology. As Yu Fengbin (Voonping Yui) put it, "China needs a medical nomenclature of her own," a crucial requirement for medicine, since his association, the National Medical Association, tended toward translating English textbooks, and Tang Erhe's- the Republic of China Medico-Pharmaceutical Association-favored German and Japanese ones (Yu 1917). As a result, very different Chinese terms might be coined depending on whether a translator aimed for translation or transliteration and whether the source material was Japanese terminology_made up primarily of easily translatable kanji (Chinese characters).

From the first two-week meeting of the Joint Committee for Medical Terminology (Yixue mingci shencha hui) in 1916 until the publication of the first official terminology list for anatomy in 1919, Tang Erhe served as representative of the national government to a group formed by leaders of China's publishing and educational circles, and staffed by medical missionaries, leading Chinese physicians, and a philologist. They determined that Chinese terms for anatomy were more important than those for other scientific fields. Debates opened up along predictable lines between missionaries who saw China as a potential tabula rasa where the errors of Latin terminology could be avoided, and Chinese physicians who found Japanese terms to be largely acceptable.

Working from the newly standardized Latin terminology, anatomia proved to be one of the longest discussions; as one missionary committee member said, "the first term is most critical" (Yu 1917, 31). Missionaries preferred their euphemism, tixue, since it included the idea of "body." Because of China's dissection taboo, they argued, jiepou, as introduced in the Han dynasty Huangdi neijing, went out of common use. But Japanese translators selected jiepou, and Chinese translators like Tang Erhe then restored it to Chinese use, an example of what Lydia Liu (1996, 313-14) has described as a return graphic loan. Participants asked: Did jiepou refer to the action of "dissection" as it had originally in English, or did it refer instead to morphological nomenclature? Would it be best to identify anatomia as the study of the body, tixue, and let the study of the outside structure of the body be called "morphology" or xingtaixue? The Encyclopædia Britannica might say that the meaning of anatomia was dissection, argued one participant, but in common usage it had the meaning of morphology. Against the missionaries' arguments negating the Japanese term jiepouxue, Tang Erhe argued that missionaries' translations had only used tixue because of the Qing law against dissection. Yet every Chinese periodical already translated anatomy as jiepou: "If we change it again," he said, "then we will never meet the day when we can have one term!" (Yu 1917,32 ). The chairman called for a vote; following Tang, a majority decided in favor of jiepouxue as the translation for anatomia.

In all, 71 percent of the terms decided for osteology-the first set of anatomical terms to be standardized - had not been represented in the Chinese language before the nineteenth century. Missionaries' neologisms were selected less than 8 percent of the time, while Japanese terms, developed throughout the nineteenth century, claimed over 24 percent of the final terms. More than half of the official terms were newly 
coined Chinese terms that were minor variations of Japanese terms, reinforcing Japan's influence in the new learning.

The new terminology for anatomy circulated in schools and through the mass media, each of which expanded dramatically in the new Republic. By 1919 there were already 4.5 million children in school, just over 20 percent of the total number of school-aged children (Bailey 1992, 203), and in school, children were exposed to the new conception of anatomy through classes in tiyu as described above, as well as biology. Biology was rooted in the comparative anatomy of humans, animals, and plants, and by the $1920 \mathrm{~s}$ classes began to include animal dissections. The change was rapid: in 1909 Jiaoyu zazhi [Education journal] published an article calling jiepou a subject that the educational world might not find of much value (Jiaoyu zazhi 1909); but after the anatomy law, by 1915, the Chinese Student World, a popular monthly from the nation's second-largest China Press, included reproductions of two photographs of medical student dissections at the National Medical College (including figure 3). Normal School students like Wu Fangsun published accounts of their physiology and dissection experience as they prepared to become teachers of the nation's children. Students wrote about their dissections of dogs, clams, turtles, crabs, silkworms, and toads in a wide variety of journals. For these students learning anatomy, "books were not as good as images, pictures were not as good as models, and models were not as good as working with the actual object" (Wu 1915).

In each of these contexts-from biology to tiyu classes, and disseminated through the mass media-the new technical terminology of jiepouxue changed the way the reading public thought and talked about the human body. The language of anatomy was one of reduction, a powerful way of speaking that required that "the world be made up of separate objects," things that "can be examined in isolation from one another and their properties measured" (Lewontin and Levins 2007, 125). This mechanistic terminology reflected industrial capitalism and transformed the vernacular language of China. Wang Hui (2006, 93) has argued that "the modern vernacular movement was rooted in the technologizing of language," its vocabulary "created by conscious, linear design." As the standardized terms for anatomy spread throughout Republican society, a new scientific worldview began to displace the Confucian cosmology; the language for a new body anatomic provided the basis of language for a new body politic.

\section{From Anatomo-politics to Biopolitics}

The key to the present argument is linking the changes following the enactment of China's anatomy law to the advent of biopower. Thus far it has been demonstrated that new knowledge about the human body obtained by the medical profession through active dissection was connected to the disciplining of bodies in government medical schools. This knowledge spread quickly after 1913 through the educational system because the newly standardized technical language allowed textbooks and the press to disseminate them unambiguously. The process was not without resistance, but continued steadily nonetheless. New disciplinary regimes that sought to shape all aspects of life extended beyond schools also to the hospitals, prisons, factories, and workhouses being established throughout Republican China, even if the subjects of such discipline rarely shared in the 
precise anatomical knowledge of the physicians and biology students who disseminated it (see Chen 2012; Dikötter 2002; Honig 1986; Yang 2006). All of these institutions that increased the level of power over the bodies of individuals thus became sites where elites and state agents could access these bodies to collect somatic measurements of height and weight and other statistical data to construct a new collective that would be known as the population. The goal was to create productive and healthy citizenry, not necessarily a sinister objective from the point of view of the individual, but a prerequisite of the expansion of biopower that was increasing the degree to which those bodies were docile and accepting of a new status quo and norms.

The goal of liberal biopower is always to move beyond an anatomo-politics attempting to produce compliant individuals through discipline and surveillance to a regime where social life is regulated from within the individuals themselves, so that the individuals are compelled to "embrace and reenact such power" even while the state and elites manage a collective "population" conceptualized through statistics (Lam 2011, 25). As Tong Lam has described, a key method of biopower is the creation of empirical social "facts." In the early Republic, Tang Erhe $(1915,2)$ also bemoaned the lack of statistical facts, particularly in the fields of education and medicine, for "without statistics then there is no way of handling things." But with certain carefully collected statistics, China might begin to address its embarrassing but ambiguous position in the global racial hierarchy.

It is beyond the scope of this article to address all of the ways that anatomy was linked to the expansion of biopower, but the most pertinent connection is through racial anatomy and anthropometry - a crucial aspect of physical anthropology in the early twentieth century and a major site of the production of large data sets of "facts" about humans. The goal of physical anthropology, according to Tang Erhe's translation of a book by Japanese anthropologist Hasebe Kotondo, was to discover the origins of humans, how they had spread throughout the world, and how they developed their facial features and skeleton, as well as customs and habits (Tang Erhe 1930). E. V. Cowdry (1920a, 58-59) thought that anatomists were "in a position to contribute valuable information relating to the physical standards and potentialities of the Chinese race," a contribution that could be accomplished through keeping records of all dissections carried out in Chinese medical schools and tabulating "the frequency of the chief progressive and regressive variations" in order to determine if Chinese were "a progressive or regressive type." As a branch of anatomy, anthropometry researched the structure, distribution, and variation of Chinese bodies, including straightforward measurements of height and weight, or measurements of the skull, eye socket, clavicle, knees, and pelvis, but also measurements of the internal organs or fibers of the brain.

Even more fundamentally, racial anatomy can be said to be a space where the cosmology of power over life, or biopower, became ensconced in China through its sophisticated measurements and statistics measuring racial affinity among living peoples of China, and between those people and the rest of the world. Anatomical knowledge was certainly of great use for medical interventions, but this knowledge also promised to bring the enlightenment of science to understand the origins, present status, and future of humankind. If medical anatomy could cut out the tumor that threatened the individual, racial anatomy promised tools to remove-or improve-the individuals who threatened the nation and the race. China had no government programs of negative 
eugenics to match those of the United States, Canada, or Germany in the first half of the twentieth century; the foundation of racial improvement, however, was first to be found in the work of painstaking measurement of the body, known as anthropometry. When measurements of skulls, stature, or chest capacity had reached a critical mass, these scientists thought, statistical data that could not be refuted would demonstrate both the current hierarchy of races, and, hopefully, a path for racial improvement. Euro-American biometricians tended to look for craniological justification of racial hierarchies on one hand, and for urban environmental causes for white degeneration on the other (Gould 1996). Japanese were lumped with Chinese and Koreans into the larger racial category of "Mongoloid," so anatomists sought to differentiate modern Japanese from the Ainu, Koreans, and Chinese through increasingly precise measurements of the anatomy and physiology of humans (Hasebe 1912; Kim 2013; Low 2012; Morris-Suzuki 1998).

Likewise, Chinese practitioners of anthropometry conducted measurements of hundreds of live participants, usually students, soldiers, and residents of hospitals, attempting to accumulate scientific facts about the Chinese population and its many regional and class-based variations, generally following Franz Boas's famous 1912 anthropometric study of immigrants in concluding that environment was more significant than natural endowments in determining bodily form. Jia-Chen $\mathrm{Fu}(2012,2016)$ argues that for anthropologists and physicians in China, body measurements would help improve the Chinese race and nation by developing public health and dietary interventions to meet deficiencies. In addition to external measurements, Tang Qi, son of Tang Erhe, published quantitative studies based on dissections of the sebaceous and sweat glands of subjects of different races—surely the fulfillment of his father's dream of transforming China through the accumulation of detailed statistical knowledge (Tang-Chi [Qi] 1940, 1941). If humans were machines, then even their exact composition might be known and transformed through careful study. Racial anatomy was where the dissection of an individual became relevant to the collective future of the nation, for if the methods of racial anatomy could lead to an understanding of enough individuals, it could then be scaled up to the level of the population, and elites and the state might prescribe policy interventions to transform the body politic.

\section{Conclusion}

After World War II, major advances in genetics along with public revulsion at Nazi racial science began to marginalize anatomic and anthropometric research within mainstream science, but a mechanistic view continues to dominate, although now at the level of the gene. But in 1924, Tang scolded Chinese biologists for jumping past anatomy to ecology (shengtai xue) — the branch of biology dealing with the relationship of organisms to each other and their environment. They were building a house without a foundation that would collapse in the wind and rain and be consumed in the fire, for "if one does not have a deep foundation in anatomy and physiology, it is like skipping over the fish to eat tofu," implying that it was anatomy that gave ecology its flavor and taste-its substance, in fact (Tang Erhe 1924). "According to biologists," Tang (1929) wrote elsewhere, "all of life originally comes from one ancestor," a fact that was discovered through the 
technique of dissection, applied to apes along with examination of the fossils of primitive man. But anatomy was as much about living things as the dead; for female physician Li Wanqiu (1916, 11), anatomy, histology, and weisheng xue (hygiene)_literally "guarding life"-were intimately connected. So biology, the study of life, was based on anatomy, the study of the dead; and there was a strong link between hygienic modernity and anatomy. Building on Ruth Rogaski's claim that weisheng xue and biopolitics can be considered two terms for the same phenomenon, these Chinese actors can be understood as making a direct link between anatomy and biopolitics.

This article has demonstrated the unrecognized role that the institutionalization of human dissection played in establishing power over individual bodies in China after the Republican revolution. The purpose has not been to give an exhaustive account of the history of anatomy in China, or to adjudicate between Chinese and Western conceptions of the body, but rather to establish that dissection-based anatomy became the basis of new modes of power over life and death for the medical profession and the state. In imperial China, perceptions of the structure of the human body were tied to the legitimacy of political power. As institutions crumbled in the onslaught of capitalist imperialism, so too did the legitimacy of the Chinese cosmological concept that the emperor mediated between the macrocosm of heaven and earth and the microcosm of the human body, and lack of accurate anatomy became the basis for rejection of all "old" forms of medicine for many modernizers. The Republic saw the establishment of a new relationship of microcosm and macrocosm and a new political legitimacy based, at least in part, in the new anatomy law. No longer residing in the ruler, legitimacy was now found among the individuals that composed the Republic: the microcosm would be the individualized human body understood through the reductive methods of anatomy, while the macrocosm would be the sum of bodies comprehended through statistical methods that counted individuals and registered disease in a new entity-the population. But before understanding aggregate populations in the biosphere, a student was first required to master the details of the life and death of the individual organism through dissection.

\section{List of References}

\section{Archival Collections}

BMA (Beijing shi dang'an guan [Beijing Municipal Archives]). 1912-15. "Neizhengbu gongbu xiuzheng jiepou fabu guanggao" [Notices regarding the Ministry of the Interior publicly announcing revised regulations on dissection]. BMA J29-1-16.

1922. Beijing Medical Professional School. BMA J29-003-16.

. 1928. "Beida yixueyuan guanyu han lingshiti ji jiepou ai-ling-tai-mai zhizhao deng wenti yu youguan danwei de laiwanghan" [Correspondence between Beijing University Medical School and (government) related work units regarding the issue of taking possession of dead bodies and licenses for carrying and burying (them)]. BMA J029-003-00582. 
—. 1931. "Beiping shizhengfu gonganju guanyu jiepou shenti di yijian" [Opinion of the Beiping Municipal Government Police regarding dissection of bodies]. BMA J181-020-05438.

_. 1939. "Beida yixueyuan zhongri jiaozhiyuan ji xuesheng xunlie qian wang Guangwai Caihuying cun jiepou shiti mudi zhi ji wenti gei Beijing tebie shizhengfu jingcha ju he Beida de han" [Correspondence between Police of Beijing Special Government and Beijing University regarding the problem of Chinese and Japanese teaching staff and students of Beijing University Medical School following past (custom) holding a ceremony at the graveyard for dissected bodies outside Guang(an Gate) at Caihuying Village]. BMA J029-003-00645.

PUhSCAC (Peking University Health Sciences Center Archives Collection). 1913. "1913 yi yue xuexiao zai jing, hu, liang di zhaoshou diyi jie xuesheng 72 ren. Tu wei diyi jie jia ban tongxue zaishang junshike” [January 1913, first class of 72 students recruited from Beijing and Shanghai. Image is of first cohort during military drill]. 1-1-15.

. 1914. "Beijing yixue zhuanmen xuexiao jiepou shixi 1914 nian” [1914 anatomy practice at Beijing Medical Professional College (National Medical College)]. 1-1-11.

RFA (Rockefeller Foundation Archives). Tarrytown, NY. 1916. Greene to Buttrick.

- 1925. Dunlop to Black.

\section{Other Sources}

Andrews, Bridie J. 2014. The Making of Modern Chinese Medicine, 1850-1960. Vancouver: University of British Columbia Press.

Bailey, Paul. 1992. Reform the People: Changing Attitudes Towards Popular Education in Early 20th Century China. Edinburgh: Edinburgh University Press.

BAO, Jianqing. 1931. "Woguo xinyi zhi jiepouxue shi” [A history of anatomy in China's new medicine]. Ziran kexue jikan 1-59.

Bartholomew, James. 1989. The Formation of Science in Japan: Building a Research Tradition. New Haven, Conn.: Yale University Press.

Bertman, Sandra. 2009. One Breath Apart: Facing Dissection. Amityville, N.Y.: Baywood Publishing.

Bonner, Thomas. 1995. Becoming a Physician: Medical Education in Britain, France, Germany, and the United States, 1750-1945. Oxford: Oxford University Press.

Boorman, Howard L., ed. 1970. Biographical Dictionary of Republican China, Volume 3, Mao-Wu. New York: Columbia University Press.

Bourgon, JÉrôme. 2004. "Rights, Freedoms, and Customs in the Making of Chinese Civil Law, 1900-1936." In Realms of Freedom in Modern China, ed. William C. Kirby, 84-112. Stanford, Calif.: Stanford University Press.

Boyle, John Hunter. 1972. China and Japan at War, 1937-1945: The Politics of Collaboration. Stanford, Calif.: Stanford University Press.

Brook, Timothy, Jérôme Bourgon, and Gregory Blue. 2008. Death by a Thousand Cuts. Cambridge, Mass.: Harvard University Press.

Chen, Janet Y. 2012. Guilty of Indigence: The Urban Poor in China, 1900-1953. Princeton, N.J.: Princeton University Press.

Chow, Tse-tsung. 1960. The May Fourth Movement: Intellectual Revolution in Modern China. Stanford, Calif.: Stanford University Press.

Cowdry, E. V. 1920a. “Anatomy in China.” Anatomical Record 20(1):32-60. 
—. 1920b. “Anatomy in Japan.” Anatomical Record 18(2):67-95.

Culp, Robert. 2007. Articulating Citizenship: Civic Education and Student Politics in Southeastern China, 1912-1940. Cambridge, Mass.: Harvard University Asia Center.

Dikötter, Frank. 2002. Crime, Punishment, and the Prison in Modern China, 18951949. New York: Columbia University Press.

Duffin, Jacalyn. 1998. To See with a Better Eye: A Life of R. T. H. Laennec. Princeton, N.J.: Princeton University Press.

Farquhar, Judith, and Qicheng Zhang. 2005. "Biopolitical Beijing: Pleasure, Sovereignty, and Self-Cultivation in China’s Capital.” Cultural Anthropology 20(3):30327.

Foucault, Michel. [1973] 1994. The Birth of the Clinic: An Archaeology of Medical Perception. New York: Vintage.

—. [1977] 1995. Discipline and Punish: The Birth of the Prison. Translated by Alan Sheridan. New York: Vintage.

—. 2003. Society Must Be Defended: Lectures at the Collège de France, 1975-1976. New York: Picador.

Fu, Jia-Chen. 2012. "Scientising Relief: Nutritional Activism from Shanghai to the Southwest, 1937-1945." European Journal of East Asian Studies 11(2):259-82.

—. 2016. "Measuring Up: Anthropometrics and the Chinese Body in Republican Period China." Bulletin of the History of Medicine 90(4):643-71.

Gluck, Carol. 2009. "Words in Motion.” In Words in Motion: Toward a Global Lexicon, eds. Carol Gluck and Anna Lowenhaupt Tsing, 3-10. Durham, N.C.: Duke University Press.

Gould, Stephen Jay. 1996. The Mismeasure of Man. New York: W. W. Norton.

Greenhalgh, Susan. 2008. Just One Child: Science and Policy in Deng's China. Berkeley: University of California Press.

Guo Qi et al. 2012. Gan en wuyan liangshi: Huodong jinian [Grateful to our silent mentor: Commemoration activity]. Beijing: Beijing University Health Science Center Basic Medicine Students General Branch.

Hasebe Kotondo. 1912. Nihon jin kaibō gaku no shinpo [The progress of the anatomical studies of Japanese people]. Jinruigaku zasshi 2(8):27-35.

Heinrich, Larissa N. 2008. The Afterlife of Images: Translating the Pathological Body Between China and the West. Durham, N.C.: Duke University Press.

Honig, Emily. 1986. Sisters and Strangers: Women in the Shanghai Cotton Mills, 19191949. Stanford, Calif:: Stanford University Press.

Jiangsu Provincial Medical College. 1913. "Jiangsu shengli yixue zhuanmen xuexiao jiepou kaishi jinian (tupian)" [Commemoration of Jiangsu Provincial Medical College's first dissection (picture)]. Jiangsu Educational Administration Monthly 7:1.

JiAOYU ZAZHI [EDUCATION JOURNAL]. 1909. "Jiaoyu jie zhi zhutou muxie: Jiepou” [Odds and ends of the education world: Dissection]. 1(3):81.

Jones, William C., trans. 1994. The Great Qing Code. Oxford: Clarendon Press.

Karl, Rebecca. 2002. Staging the World: Chinese Nationalism at the Turn of the Twentieth Century. Durham, N.C.: Duke University Press.

Ke Feng. 1937. "Jiepou shi [shige]” [Dissecting a corpse: A poem]. Guang Ming 2(8): 1304-6.

KIm, Hoi-eun. 2013. "Anatomically Speaking: The Kubo Incident and the Paradox of Race in Colonial Korea." In Race and Racism in Modern East Asia: Western and Eastern Connections, eds. Rotem Kowner and Walter Demel, 411-30. Leiden: Brill. 
Lam, Tong. 2011. A Passion for Facts: Social Surveys and the Construction of the Chinese Nation-State, 1900-1949. Berkeley: University of California Press.

Lei, Sean Hsiang-Lin. 2009. "Moral Community of Weisheng: Contesting Hygiene in Republican China." East Asian Science, Technology and Society: An International Journal 3(4):475-504. doi:10.1007/s12280-009-9109-2.

_ 2014. Neither Donkey nor Horse: Medicine in the Struggle over China's Modernity. Chicago: University of Chicago Press.

Lewontin, Richard, and Richard Levins. 2007. Biology Under the Influence: Dialectical Essays on Ecology, Agriculture, and Health. New York: Monthly Review Press.

Li WanQIU. 1916. "Jianming jiepouxue shuyao" [A brief explanation of anatomy]. Funü zazhi 2(1):11-18.

Liu, Lydia H. 1996. Translingual Practice: Literature, National Culture, and Translated Modernity-China, 1900-1937. Berkeley: University of California Press.

Liu, Michael Shiyung. 2009. Prescribing Colonization: The Role of Medical Practices and Policies in Japan-Ruled Taiwan, 1895-1945. Ann Arbor, Mich.: Association for Asian Studies.

Low, Morris. 2012. "Physical Anthropology in Japan: The Ainu and the Search for the Origins of the Japanese." Current Anthropology 53(S5):S57-S68.

Lu Xun. 1922. "Mr. Fujino" in Dawn Blossoms Plucked at Dusk; "Preface," Call to Arms. Marxists Internet Archive, http://www.marxists.org/archive/lu-xun/1922/12/03.htm (accessed January 30, 2009).

Lynteris, Christos. 2011. "From Prussia to China: Japanese Colonial Medicine and Gotō Shinpei's Combination of Medical Police and Local Self-Administration." Medical History 55(3):343-47.

Mai, Menghua. 1898. Lun Zhongguo yi zun junquan yi minquan [Should China follow monarchy or democracy?]. http://www.cmingde.com/ctw_18066/370.html (accessed May 20, 2016; URL now defunct).

Morris, Andrew D. 2004. Marrow of the Nation: A History of Sport and Physical Culture in Republican China. Berkeley: University of California Press.

Morris-Suzuki, Tessa. 1998. "Debating Racial Science in Wartime Japan.” Osiris 13(1): 354-75.

Mou, Bin. 1929. “Shenti geming” [Body revolution]. Mingri zhi Jiangsu 4:10.

Mühlhahn, Klaus. 2009. Criminal Justice in China: A History. Cambridge, Mass.: Harvard University Press.

Nagayo, Mataro. 2001. Nagayo Mataro nikki: Kindaika o suishinshita igakusha no kiroku [Diary of Nagayo Mataro: Record of a medical scientist who promoted modernization]. Vol. 1-2. Tokyo: Odaka Takeshi hen.

Neighbors, Jennifer. 2004. "Criminal Intent and Homicide Law in Qing and Republican China.” PhD diss., University of California, Los Angeles.

Reynolds, Douglas. 1993. China 1898-1912: The Xinzheng Revolution and Japan. Cambridge, Mass.: Council on East Asian Studies, Harvard University, distributed by Harvard University Press.

Rogaski, Ruth. 2004. Hygienic Modernity: Meanings of Health and Disease in TreatyPort China. Berkeley: University of California Press.

Schwartz, Benjamin. 1964. In Search of Wealth and Power: Yen Fu and the West. Cambridge, Mass.: Belknap Press of Harvard University Press.

Shenbao [Shanghai news]. 1914. "Bu ding jiepou guize zhi fanduizhe” [Opponents of the government dissection law]. March 15. 
—. 1923. "Tongji xuexiao qing ling shiti jiepou banfa" [Tongji School requests a method to acquire bodies for dissection]. July 27.

—. 1935. "Quanguo yishi hui gongbu bingli jiepou tongzhi hui jianzhang" [National Physicians Association announces pathological anatomy comrades committee general regulations]. November 9.

Sigley, Gary. 2009. "Suzhi, the Body, and the Fortunes of Technoscientific Reasoning in Contemporary China.” positions 17(3):537-66.

Sivin, Nathan. 1995. "State, Cosmos, and Body in the Last Three Centuries B.C." Harvard Journal of Asiatic Studies 55(1):5-37.

Tan Sitong. [1898] 1981. "Lun quanti xue" [Discourse on the whole body]. In Tan Sitong quanji [Complete works of Tan Sitong]. Taipei: Zhonghua shuju.

—. 1911. "Tan Fusheng guancha di ba ci jiangyi (lun quantixue)" [Tan Fusheng [Sitong]'s observations: Commentary number 8 (A discourse on the whole body)]. Xiangbao leizuan yishang, 22-44.

TANG ERhe. 1915. “Tang Erhe xiansheng jiangyan ying’er baoyufa jilu” [A record of Mr. Tang Erhe's lecture on infant and child welfare]. Jiangsu sheng jiaoyu hui bianyin, linshi kanbu 6.

—. 1917. "Cheng jiaoyubu qingzhengqing yishi yubei kaiye shiyan you" [A request for the Ministry of Education to enact procedures to regulate physicians]. Zhonghua Minguo yiyao xuehui huibao 1:5.

—. 1924. "Preface." In Yixue yu zhexue [Igaku to tetsugaku (Medicine and philosophy)] by Nagai Hisonu. Shanghai: Commercial Press.

—. 1929. "Translator's Foreword." In Shengwu xue jingyi [Essentials of biology] by Okamura Shūtei. Shanghai: Shangwu yinshuguan.

—_, trans. 1930. Ziran renlei xue gailun [Outline of natural anthropology]. Shanghai: Shangwu yinshuguan.

Tang Erhe and Chen Duxiu. 1918. “Sanjiao! Dantian!” [Triple burner! Cinnabar field!]. Xin qingnian 4(5):483-84.

TAng Yousong (QI). 1942. Tang Erhe Xiansheng [Mr. Tang Erhe]. Beijing: Jinhua yinshu ju.

TANG-Chi (QI). 1940. “Talgdrusen bei verschiedenen rassen und altersstufen” [Sebaceous glands in different races and ages]. Guoli Beijing daxue yixueyuan lunwenji 2(2): 397-415.

—. 1941. "Verteilung des arrektors beim menschen" [Distribution of the human arrectors (pili muscle)]; "Die körperbehaarung bei den Chinesen" [The distribution of hair on a Chinese man]. Guoli Beijing daxue yixueyuan lunwenji 3(2):183-96.

TAYlor, George E. 1940. The Struggle for North China. New York: Institute for Pacific Relations.

Thompson, Malcolm. 2012. "Foucault, Fields of Governability, and the PopulationFamily-Economy Nexus in China." History and Theory 51(1):42-62.

Wan, Weicun. 1934. "Tiyu jichu shengli jiepouxue (1)" [Basic physiology and anatomy for physical culture (1)]. Qinfen tiyu yuebao 2(3):40-43.

Wang Hur. 2006. "Discursive Community and the Genealogy of Scientific Categories.” In Everyday Modernity in China, eds. Madeline Yue Dong and Joshua Goldstein, 80120. Seattle: University of Washington Press.

Warner, John Harley, and Lawrence J. Rizzolo. 2006. "Anatomical Instruction and Training for Professionalism from the 19th to the 21st Centuries." Clinical Anatomy 19(5):403-14. 
Weiner, Dora B., and Michael J. Sauter. 2003. "The City of Paris and the Rise of Clinical Medicine." Osiris, 2nd ser., 18(1):23-42.

Wong Chi-min and Wu Lien-ten. 1936. History of Chinese Medicine: Being a Chronicle of Medical Happenings in China from Ancient Times to the Present Period. 2nd ed. Shanghai: National Quarantine Service, Mercury Press.

Wu, Fangsun. 1915. "Ji shengli jiepou zhi shiyan" [A record of a physiological dissection experiment]. Zhonghua funü jie 1(6):3-4.

Xu, Youchun. 1991. Minguo renwu dacidian [Republican biographical dictionary]. Shijiazhuang: Hebei renmin chubanshe.

YANG, NiAnQun. 2006. Zaizao "bingren": Zhongxi yi chongtu xia de kongjian zhengzhi, 1832-1985 [Remaking "patients": The spatial politics of the conflict between Chinese and Western medicine]. Beijing: Renmin University Press.

YING XING. 2009. Cunzhuang shenpan shi zhong de daode yu zhengzhi: 1951-1976 nian Zhongguo xinan yige shancun de gushi [Morality and politics in the history of village trials: A story from a southeastern Chinese village]. Beijing: Zhishi chanquan chubanshe.

Yu Fengbin. 1917. "Yixue mingci shenchahui di yi ci kaihui jilu" [Minutes of the first meeting of the medical terms investigation committee]. Zhonghua yixue zazhi 3 (2):30-60.

Yue, Meng. 2006. Shanghai and the Edges of Empires. Minneapolis: University of Minnesota Press.

Zarrow, Peter. 2012. After Empire: The Conceptual Transformation of the Chinese State, 1885-1924. Stanford, Calif.: Stanford University Press.

Zeng Jian. 1933. "Jiepou shi xunli” [Pilgrimage to the dissection room]. Qinghua zhoukan 40(10):84-88.

Zhan, Mei. 2011. "Human Oriented? Angels and Monsters in China’s Health-Care Reform." East Asian Science, Technology and Society: An International Journal 5 (3):291-311.

Zito, Angela. 1997. Of Body and Brush: Grand Sacrifice as Text/Performance in Eighteenth-Century China. Chicago: University of Chicago Press. 